\title{
Youtube Contents Effect on Destination Visit Intentions an Empirical Study in Indonesia
}

\author{
Siti Rahayu \\ Management Department, Business and Economics Faculty \\ Universitas Surabaya \\ Surabaya, Indonesia \\ s_rahayu@staff.ubaya.ac.id
}

\author{
Sugeng Hariadi \\ Economics Department, Business and Economics Faculty \\ Universitas Surabaya \\ Surabaya, Indonesia \\ sugeng.hariadi@staff.ubaya.ac.id
}

\begin{abstract}
Currently, online videos have become the dominant means of information and education. When determining tourist destination visits, YouTube contents play an important role. YouTube content is created by travelers to share experiences, which helps other potential travelers. This study aims to comprehend how tourists assume information over YouTube content and how this affects the tourist destination according to their intentions. The study model was built and tested empirically using a sample of 154 Indonesian respondents who observed YouTube content before attending a destination. Furthermore, this research hypothesis is validated with the assistance of SEM using PLS. This study found that comprehensiveness and attitude were the utmost significant predictors of tourist destination intention over YouTube content adoption. Furthermore, relevance, source expertise, source trustworthiness, accuracy, and timeliness were not found to be statistically significant.
\end{abstract}

Keywords: YouTube content, destination, Intension, SEM, PLS

\section{INTRODUCTION}

Nowadays, online videos have proven to be the most dominant means of information and education [1]. Internet users rely a lot on online information when procurement goods or services [2].

Internet usage is also broadly used for tourist activities. Many vacationers share experiences about the quality of tourist attractions along with ratings and reviews through various social media platforms such as Facebook, Instagram, Twitter [3] [4].

Subsequently its establishment in 2005, YouTube has become the largest online video distribution website in the world [1]. YouTube users create and upload videos and hundreds of millions of people can view and share them [5] [6].

Social media and online video distribution websites are the most effective channels for promoting tourist destinations [7]. Videos about tourist destinations are a powerful medium to enhance the image of tourist destinations and help increase the number of tourists visiting these tourist destinations [8].

This study explores the influence of YouTube Contents on Indonesian tourists in choosing tourist destinations. Reaching 9 out of 10 netizens are viewers, YouTube is the largest among other social media (https://techbiz.id and https://katadata.co.id). The management of tourist destinations in Indonesia has also carried out many promotions by inviting content creators from YouTube.

\section{LITERATURE REVIEW AND HYPOTHESIS}

\section{A. Source Expertise}

Source Expertise is the intention of someone who believes that the information provided by the source is valid [9] [10]. If consumers feel the expertise possessed by the source is higher, the source will have a greater influence, and is considered to provide useful information [11] [12] [13] [14] [15]. The hypothesis tested:

H1: Source expertise has a positive influence on information usefulness.

\section{B. $\quad$ Source Trustworthiness}

Source Trustworthiness refers to the correctness of information provided by a person, this factor becomes important because of the demand to be critical in seeking information, when the source has good integrity, the information from that source is more reliable [16] [17] [18]. The hypothesis tested:

$\mathrm{H} 2$ : Source trustworthiness has a positive effect on information usefulness.

\section{Accuracy}

Accuracy is needed when looking for information in online media. Accuracy is the user's perception that the information provided is correct [19] [20] [21]. Hypothesis tested:

H3: Accuracy has a positive effect on information usefulness

D. Timeliness

Punctuality is important when looking for information. Timely information is information that is updated consistently, timely and up to date [22] [23] [24]. The hypothesis developed:

H4a: Timeliness has a positive effect on information usefulness

H4b: Timeliness has a positive effect on tourist's information

\section{E. Usefulness Relevance}

The relevance of information is the linkage of information which has a close and similar relationship. Relevance in decision making is an important factor, because information is not only accurate but also relevant [25] [26] [27] [28]. The hypothesis developed: 
H5a: Relevances have a positive effect on information adoption

H5b: Relevances have a positive effect on tourist's destination visits intention

\section{F. $\quad$ Comprehensiveness}

Comprehensiveness related to the completeness of messages given by a source (online / offline). When the information provided is complete, someone will be interested in reading. A person's orientation for using the website becomes more when detailed information is provided [29] [1]. Hypothesis developed:

H6a: Comprehensiveness has a positive effect on information usefulness

H6b: Comprehensiveness has a positive effect on information adoption

H6c: Comprehensiveness has a positive effect on destination visits

\section{G. $\quad$ Attitude}

Attitudes are all actions and actions based on the position and belief that a person has, when someone gives a statement to everything, it can be an object, person or event. Attitudes reflect a person's feelings towards something [30] [31] [32]. The hypothesis stated:

H7a. Attitude has a positive effect on information adoption $\mathrm{H} 7 \mathrm{~b}$. Attitude has a positive influence on destination visit intention

\section{H. Information Usefulness}

In order to search for information, there is a tendency to look for its uses. The usefulness of information is a strong determinant of information adoption in various contexts, including online consumer reviews [33] [34]. The hypotheses developed:

H8. Information usefulness has a positive effect on tourist's information adoption

\section{Information Adaption}

Before making a decision, a variety of information is often adopted to avoid problems. The usual way is to scan opinions and comments posted by experienced consumers and ask questions for which we want information [35] [13] [36] [37] [38] [39]. The hypothesis developed:

H9. Information adoption has a positive effect on tourist's destination visit intention

\section{J. Destination Visit Intention}

Destination Visit Intention emphasizes the intention of tourists to return to tourist attractions within a certain period of time [36]. Visit Intention refers to the probability of what tourists feel at one time so that it can build a subjective perception that will influence tourists' behavior and decisions in visiting tourist attractions [39].

\section{RESEARCH METHOD}

This research is a causal study. Respondents are those who frequently watch travel review videos on YouTube in the past 1 year. The sampling technique used was non-probability sampling, namely purposive sampling. The research model was built and tested empirically using a sample of 154 Indonesian respondents who observed YouTube content before attending a destination. Furthermore, this research hypothesis is validated with the assistance of SEM using PLS. This study customs AMOS for data processing.

\section{RESULT, DISCUSSION AND CONCLUSION}

The validity and reliability test of the questionnaire using 30 respondents showed that the item statements of the variable source expertise, source trustworthiness, accuracy, timeliness, relevance, comprehensiveness, attitude, usefulness, information adaptation, and destination visit intention were valid and reliable.

The number of respondents in this study was 154 people and was dominated by females (72.9\%). Respondents aged 21-35 years also dominate $(72.1 \%)$. As many as $65 \%$ of the respondents are students. All respondents are YouTube users and have seen travel content on various YouTube channels.

The results of processed data using SEM with AMOS in Table 1 show that the overall model tested has met the required criteria.

TABLE 1. GOODNESS OF FIT OF THE MEASUREMENT MODEL

\begin{tabular}{|l|c|c|c|}
\hline Goodness of fit & Criteria & Model Result & Description \\
\hline CMIN/DF & $\leq 3.00$ & 1.626 & Good Fit \\
\hline RMSEA & $\leq 0.08$ & 0.064 & Good Fit \\
\hline GFI & $\geq 0.90$ & 0.804 & Marginal Fit \\
\hline TLI & $\geq 0.90$ & 0.941 & Good Fit \\
\hline CFI & $\geq 0.90$ & 0.929 & Good Fit \\
\hline
\end{tabular}

The results of the structural model processing in Table 2 show that the model is accepted based on the overall model testing, confirmatory factor analysis, and structural model analysis.

TABLE 2. STRUCTURAL MEASUREMENT MODEL

\begin{tabular}{|l|c|c|c|}
\hline Goodness of fit & Criteria & Model Result & Description \\
\hline Cmin/DF & $\leq 3.00$ & 1.579 & Good Fit \\
\hline RMSEA & $\leq 0.08$ & 0.062 & Good Fit \\
\hline GFI & $\geq 0.90$ & 0.800 & Marginal Fit \\
\hline TLI & $\geq 0.90$ & 0.937 & Good Fit \\
\hline CFI & $\geq 0.90$ & 0.926 & Good Fit \\
\hline
\end{tabular}


Table 3 shows that in this study, the supported hypotheses are H6a, H7a, H8, H6c, H7b, and H9. H6a is supported, that is, there is a comprehensiveness effect on usefulness. This means that knowledgeable and valuable content is deemed useful to users of YouTube travel content. H7a also shows that there is an influence between attitudes and usefulness. A good YouTube user attitude shows that travel content is useful for its users.

TABLE 3. HYPOTHESIS TEST

\begin{tabular}{|l|l|l|l|l|l|c|}
\hline $\begin{array}{c}\text { Hypo } \\
\text { thesis }\end{array}$ & & $\begin{array}{c}\text { Esti } \\
\text { mate }\end{array}$ & \multicolumn{1}{|c|}{ S.E. } & C.R. & \multicolumn{1}{|c|}{} & $\begin{array}{c}\text { Sup } \\
\text { ported }\end{array}$ \\
\hline $\mathrm{H} 1$ & $\mathrm{SE} \rightarrow \mathrm{U}$ & 0.095 & 0.161 & 0.589 & 0.556 & No \\
\hline $\mathrm{H} 2$ & $\mathrm{ST} \rightarrow \mathrm{U}$ & -0.069 & 0.149 & -0.461 & 0.645 & No \\
\hline $\mathrm{H} 3$ & $\mathrm{AC} \rightarrow \mathrm{U}$ & -0.006 & 0.114 & -0.052 & 0.959 & No \\
\hline H4a & $\mathrm{T} \rightarrow \mathrm{U}$ & -0.027 & 0.117 & -0.227 & 0.821 & No \\
\hline H5a & $\mathrm{R} \rightarrow \mathrm{U}$ & 0.029 & 0.091 & 0.324 & 0.746 & No \\
\hline H6a & $\mathrm{C} \rightarrow \mathrm{U}$ & 0.754 & 0.25 & 3.01 & 0.003 & Yes \\
\hline H7a & AT $\rightarrow \mathrm{U}$ & 0.442 & 0.192 & 2.295 & 0.022 & Yes \\
\hline H6b & $\mathrm{C} \rightarrow \mathrm{IA}$ & -0.549 & 0.544 & -1.01 & 0.313 & No \\
\hline H8 & $\mathrm{U} \rightarrow \mathrm{IA}$ & 1.313 & 0.455 & 2.884 & 0.004 & Yes \\
\hline H4b & $\mathrm{T} \rightarrow \mathrm{DV}$ & -0.182 & 0.129 & -1.409 & 0.159 & No \\
\hline H6c & $\mathrm{C} \rightarrow \mathrm{DV}$ & 0.35 & 0.137 & 2.548 & 0.011 & Yes \\
\hline H5b & $\mathrm{R} \rightarrow \mathrm{DV}$ & 0.07 & 0.094 & 0.751 & 0.453 & No \\
\hline H7b & AT $\rightarrow$ DV & 0.569 & 0.168 & 3.383 & $* * *$ & Yes \\
\hline H9 & IA $\rightarrow$ DV & 0.139 & 0.077 & 1.799 & 0.072 & Yes \\
\hline
\end{tabular}

H8 also finds a relationship between usefulness and information adaptation. If users feel that the information obtained is useful, the information obtained will be used as input in making travel decisions. H6c indicates that comprehensiveness has an effect on destination visit intention. This means that if travel content on YouTube provides knowledge and value, this will lead to the desire to visit tourist destinations according to the information in the content.

$\mathrm{H} 7 \mathrm{~b}$ proves that there is an effect of attitudes on destination visit intention. A good attitude towards travel content will lead to the desire to visit the destinations that are conveyed in the content. $\mathrm{H} 9$ also proves that there is an effect of information adaption on destination visit intention. This means that if the user feels the information obtained is useful, the user will have the desire to visit the destination in the tourist content.

$\mathrm{H} 1$ and $\mathrm{H} 3$ state that there is a significant positive influence between source expertise and accuracy variables on usefulness. The usefulness of travel information conveyed via YouTube is often not influenced by whether the source in the content is an expert or not. Sometimes the source in the content is just a person who is traveling and then wants to share his activity through the content. Sources in the content can also be people who have visited a destination for the first time, so the information provided is not necessarily accurate.
H5a shows that there is no relationship between relevance and usefulness. YouTube users will see relevant content as content that is useful in making decisions. Usually, users will see some relevant content and complementary information.

$\mathrm{H} 4 \mathrm{~b}$ finds a relationship between timeliness and destination visits, that is, content users when they need information will usually search for related destinations. Sometimes the information submitted is not the latest information, as long as it is still relevant to the user's wishes in finding destination information.

$\mathrm{H} 5 \mathrm{~b}$ proves that there is an effect of relevance on destination visit intention. Relevant information is important information in deciding whether a user wants to visit a tourist destination. H6b shows that quality, knowledgeable, and valuable information does not necessarily motivate users to visit tourist destinations.

\section{REFERENCES}

[1] Arora, N. and Lata, S., "YouTube channels influence on destination visit intentions", Journal of Indian Business Research, Vol. 12, pp. 23-42, 2020.

[2] Rejikumar, G. and Asokan, A.A., "Information seeking behavior causing satisfaction modification intentions an empirical study to address emerging challenges in a service context", Journal of Indian Business Research, Vol. 9, pp.304-328, 2017.

[3] Srabanti, M., Adhikari, A. and Datta, B., "Quality of tourism destination-a scale development", Journal of Indian Business Research, 2018.

[4] Li, H. and Liu, Y., "Understanding post-adoption behaviors of e-service users in the context of online travel services", Information and Management, Vol.51, pp.1043-1052, 2014.

[5] Freeman, B. and Chapman, S., "Is 'YouTube' telling or selling you something? Tobacco content on the YouTube video-sharing website", Tobacco Control, Vol. 16, pp. 207-210, 2007.

[6] Lee, J.E. and Watkins, B., "YouTube vloggers' influence on consumer luxury brand perceptions and intentions", Journal of Business Research, Vol. 69, pp. 5753-5760, 2016.

[7] Huertas, A., Míguez-González, M.I. and Lozano-Monterrubio, N., "YouTube usage by Spanish tourist destinations as a tool to communicate their identities and brands", Journal of Brand Management, Vol.24, pp.211-229, 2017.

[8] Tsai, H.Y.S., Shillair, R. and Cotten, S.R., "Social support and "playing around' an examination of how older adults acquire digital literacy with tablet computers", Journal of Applied Gerontology, Vol.36, pp.29-55, 2017.

[9] Ayeh, J.K., Au, N. and Law, R., “'Do we believe in TripAdvisor?' Examining credibility perceptions and online travelers' attitude toward using user-generated content", Journal of Travel Research, Vol.52, pp.437-452, 2013.

[10] Engel, J. F., Roger. D. B. and Paul. W. M, Consumer Behavior, Jakarta. Bina Rupa Aksara,1995.

[11] Shanteau, J., Weiss, D.J., Thomas, R.P. and Pounds, J.C., "Performancebased assessment of expertise: how to decide if someone is an expert or not", European Journal of Operational Research, Vol.136, pp.253-263, 2002.

[12] Yang, C. Huang, C.R. and Yang, K.C., "eWOM: the effects of online consumer information adoption on purchasing decision", Marketing Trends Congress, 2011

[13] Cheung, C.M., Lee, M.K. and Rabjohn, N., "The impact of electronic word-of-mouth: the adoption of online opinions in online customer communities", Internet Research, Vol.18, pp.229-247, 2008.

[14] Dou, X., Walden, J.A., Lee, S. and Lee, J.Y., "Does source matter? Examining source effects in online product reviews", Computers in Human Behavior, Vol. 28, pp. 1555-1563, 2012.

[15] Lee, H.A., Law, R. and Murphy, J., "Helpful reviewers in TripAdvisor, an online travel community", Journal of Travel and Tourism Marketing, Vol. 28, pp. 675-688, 2011 
[16] Hovland, C.I., Janis, I.L. and Kelley, H.H., Communication and Persuasion: Psychological Studies of Opinion Change, Yale University Press, 1953.

[17] Khammash, M. and Griffiths, G.H., "ArrivederciCIAO.com, BuongiornoBing.com'-electronic word-of-mouth (eWOM), antecedences and consequences", International Journal of Information Management, Vol.31, pp.82-87, 2011.

[18] Friedman, H.H., Santeramo, M.J. and Traina, A., "Correlates of trustworthiness for celebrities", Journal of the Academy of Marketing Science, Vol.6, pp.291-299, 1978.

[19] Wixom, B.H. and Todd, P.A., "A theoretical integration of user satisfaction and technology acceptance", Information Systems Research, Vol.16, pp.85-102, 2005.

[20] Nelson, V., "Representation and images of people, place and nature in Grenada's tourism", Geografiska Annaler: Series B, Human Geography, Vol.87, pp.131-143, 2005.

[21] Yu, Y.W. and Natalia, Y., "The effect of user generated video reviews on consumer purchase intention", in 2013 Seventh International Conference on Innovative Mobile and Internet Services in Ubiquitous Computing, IEEE, pp.796-800, 2013

[22] Madu, C.N. and Madu, A.A., "Dimensions of e-quality", International Journal of Quality and Reliability Management, Vol.19, pp.246-258, 2002 ,

[23] Ukago, K., "Factors that influence the timeliness of financial reporting are empirical evidence of issuers on the Jakarta Stock Exchange", Maksi Vol.5, pp. 13-33, 2005.

[24] Cheung, C.M. and Thadani, D.R., "The impact of electronic word-ofmouth communication: a literature analysis and integrative model", Decision Support Systems, Vol.54, pp. 461-470, 2012.

[25] Dunk, A.S., "Product life cycle cost analysis: the impact of customer profiling, competitive advantage, and quality of is information", Management Accounting Research, Vol.15, pp.401-414, 2004.

[26] Ainon, M., Guide to using motivation theory at work, Kuala. Lumpur, Printing Zapar Sdn. Bhd. Cet. Third, 2005.

[27] Green, R., Topical relevance Relationship. I. Why topic matching fails. J.Amer.Soc. Information Sci., 1995.

[28] Filieri, R. and McLeay, F., "E-WOM and accommodation an analysis of the factors that influence travelers' adoption of information from online review", Journal of Travel Research, Vol.53, pp.44-57, 2014.

[29] Cheung, C.M., Lee, M.K. and Rabjohn, N., "The impact of electronic word-of-mouth: the adoption of online opinions in online customer communities", Internet Research, Vol.18, pp.229-247, 2008.

[30] Ajzen, I., "Attitude structure and behavior", Attitude Structure and Function, Vol.241, p.274, 1989.

[31] Jalilv and, M.R. and Samiei, N., "The impact of electronic word of mouth on a tourism destination choice: Testing the theory of planned behavior (TPB)", Internet Research, Vol.22, pp.591-612, 2012.

[32] Azwar, S., Human Attitudes, Theory and Measurement, Yogyakarta: Pustaka Pelajar, 2003.

[33] Bailey, J.E. and Pearson, S.W., "Development of a tool for measuring and analyzing computer user satisfaction", Management Science, Vol.29, pp.530-545, 1983.

[34] Hsu, C.L., Chuan-Chuan Lin, J. and Chiang, H.S., "The effects of blogger recommendations on customers' online shopping intentions", Internet Research, Vol.23, pp. 69-88, 2013.

[35] Lee, K., "The influence of beauty-Related YouTube content on consumers' purchase intention", Master's Thesis, University of Tennessee, 2018.

[36] Cheng, V.T. and Loi, M.K., "Handling negative online customer reviews: the effects of elaboration likelihood model and distributive justice", Journal 